\title{
Improved assay to detect Plasmodium falciparum using an uninterrupted, semi-nested PCR and quantitative lateral flow analysis
}

Serge Y Ongagna-Yhombi ${ }^{1,5}$, Paul Corstjens², Eran Geva' ${ }^{1}$, William R Abrams ${ }^{1}$, Cheryl A Barber ${ }^{1}$, Daniel Malamud ${ }^{1 *}$ and Sungano Mharakurwa ${ }^{3,4}$

\begin{abstract}
Background: A rapid, non-invasive, and inexpensive point-of-care (POC) diagnostic for malaria followed by therapeutic intervention would improve the ability to control infection in endemic areas.

Methods: A semi-nested PCR amplification protocol is described for quantitative detection of Plasmodium falciparum and is compared to a traditional nested PCR. The approach uses primers that target the P. falciparum dihydrofolate reductase gene.

Results: This study demonstrates that it is possible to perform an uninterrupted, asymmetric, semi-nested PCR assay with reduced assay time to detect $P$. falciparum without compromising the sensitivity and specificity of the assay using saliva as a testing matrix.

Conclusions: The development of this PCR allows nucleic acid amplification without the need to transfer amplicon from the first PCR step to a second reaction tube with nested primers, thus reducing both the chance of contamination and the time for analysis to < two hours. Analysis of the PCR amplicon yield was adapted to lateral flow detection using the quantitative up-converting phosphor (UCP) reporter technology. This approach provides a basis for migration of the assay to a POC microfluidic format. In addition the assay was successfully evaluated with oral samples. Oral fluid collection provides a simple non-invasive method to collect clinical samples.
\end{abstract}

Keywords: Malaria, Detection, Semi-nested PCR, PCR, Lateral flow, Plasmodium falciparum

\section{Background}

Malaria, a mosquito-borne disease caused by parasites of the Plasmodium genus, exacts a global toll of at least 216 million clinical cases and 655,000 deaths annually of which $\sim 85 \%$ are children under the age of five [1]. Currently, diagnosis of malaria is based on four different approaches: microscopy, antigen detection using immunochromatographic rapid diagnostic tests (RDTs), malaria antibody detection, and nucleic acid-based assays. Microscopy remains the "gold standard" method for laboratory confirmation of malaria, and involves examination of thick and thin blood films stained with Romanowsky stain (mainly Giemsa or Field stain). However, microscopic

\footnotetext{
* Correspondence: daniel.malamud@nyu.edu

'Department of Basic Science, NYU College of Dentistry, New York, NY, 10010, USA

Full list of author information is available at the end of the article
}

diagnosis of malaria is dependent on the personnel performing and interpreting the results, and requires specialized equipment that is difficult to support in remote areas lacking a reference laboratory. Moreover, low parasitaemia, especially in asymptomatic subjects, is not detected by microscopy.

To alleviate some of the difficulties of microscopy-based diagnosis of malaria, RDTs that detect parasite-specific antigens were developed [2]. The most commonly targeted malaria antigens are Plasmodium falciparum histidinerich protein-2 (pfHRP2) and Plasmodium lactate dehydrogenase (pLDH) [3-6]. RDTs offer ease of operation, a timely diagnosis, and do not require trained personnel or special equipment $[2,7]$. However, they are relatively expensive and prone to false-positive responses due to persistence of pfHRP2 antigen in blood for up to two weeks after the parasite is cleared $[2,8]$. Also, the relatively low 
RDT sensitivity is a constraint for endemic regions attempting malaria pre-elimination, where detection and treatment of low-grade reservoir infections is required for effective elimination of infection [9].

In recent years, a molecular approach has been used to detect Plasmodium nucleic acids circulating in blood, saliva, and other body fluids [10-13]. Polymerase chain reaction (PCR) is more accurate and sensitive than microscopy and RDTs, detects low-grade parasitaemia and is indicative of active infection [14,15]. Detection and amplification of Plasmodium DNA is generally performed using nested PCR, a two-step procedure in which the product of the initial reaction is amplified a second time with a new pair of "inner" primers that hybridize to the dihydrofolate reductase (DHFR) gene located within the previously amplified region $[10,16]$. Nested PCR typically requires transfer of a small amount of product from the first step to serve as template for the second amplification in a second tube. The requirement to transfer PCRamplified products dramatically increases the risk of carry-over and environmental contamination. Moreover, the two rounds of amplification may require up to six hours to complete. Investigators have attempted to develop single-tube nested or closed-tube nested PCRs to eliminate the transfer procedure and thus minimize contamination, reducing false-positive results, and maintaining high sensitivity [17]. However, to date, despite the high sensitivity and low risk of carry-over contamination associated with a single-tube nested PCR, this technique is susceptible to inhibition by inappropriate sample preparation [17]. Real-time PCR also minimizes contamination, but nesting is needed to optimize the limit of detection (LOD) $[18,19]$. Also, the common use of SYBR Green DNA-intercalating dye in many real-time PCR kits, which binds any double strand DNA, makes the assay less specific and prone to false-positive results. Furthermore, the use of specific fluorescent probes for certain types of qPCR, although specific, are expensive which greatly diminishes their routine use [20].

A generic platform [21-23] was developed to analyse HIV and other pathogen-related antigens, antibody, and nucleic acids in saliva or blood simultaneously by a combination of RT-PCR and an immunoassay with detection by up-converting phosphors (UCP) label and lateral flow technology [21,24-26]. The UCP reporter converts photons of lower energy infrared light into higher energy visible light and is ultrasensitive since this unique process does not demonstrate autofluoresence [27]. Using a similar approach an uninterrupted, asymmetric, semi-nested PCR providing quantitative detection of a $P$. falciparum DNA target with a significant reduction in overall assay time and improved robustness with respect to reducing the probability of contamination was developed. The system is ideal for further development to a point-of-care (POC) device.

\section{Methods}

\section{Samples and instrumentation}

DNA from $P$. falciparum laboratory clone 3D7 was provided by Professor Karen Day, New York University School of Medicine. The 3D7 DNA was adjusted to a working concentration of $270 \mathrm{ng} / \mu \mathrm{l}$ and used as positive control for the PCR assays. Unstimulated whole saliva samples $(5 \mathrm{ml})$ were collected in the area surrounding the Malaria Institute at Macha (MIAM, Choma, Zambia) from patients tested positive for malaria by microscopy [11]. The specimens were transported to the Malaria Institute at Macha laboratory within a few hours of collection, where they were aliquoted into $1 \mathrm{ml}$ amounts and stored at $-20^{\circ} \mathrm{C}$. Ten-fold serial dilutions of P. falciparum NF54 culture, donated by Dr Godfree Mlambo, Johns Hopkins Bloomberg School of Public Health, were used to determine the parasite detection threshold, and negative controls lacking template were included to preclude contamination. All amplifications were performed using a DNA engine DYAD PCR (BioRad). Digital quantification of amplicon from gel images employed ImageJ [28] or ImageQuant software (ImageQuant, GE Healthcare Life Sciences, Piscataway, NJ, USA).

\section{Isolation of malaria DNA from saliva and dried blood}

Whole saliva samples $(1 \mathrm{ml})$ were centrifuged at $8,000 \mathrm{rpm}$ for $3 \mathrm{~min}$. Essentially all of the DNA was in the pellet, which was then extracted using the crude cell lysate protocol of the Qiagen DNAeasy ${ }^{\circledR}$ Blood and Tissue kit (Qiagen, Valencia, CA, USA) according to the manufacturer's instructions and DNA eluted in $8 \mu \mathrm{l}$ of distilled $\mathrm{H}_{2} \mathrm{O}$.

Whole blood samples were spiked with a titer of $P$. falciparum parasite and then $\sim 100 \mu \mathrm{l}$ was dried on Whatman filter paper. A Qiagen QIAamp DNA mini kit was used to isolate parasite DNA from six 3-mm diameter punches (Harris Punch) from the dried filter paper in a total volume of $150 \mu \mathrm{l}$ distilled $\mathrm{H}_{2} \mathrm{O}$.

\section{Primers used for PCR amplification reactions}

The initial studies employed genus-specific primers rPLU1/rPLU5 for the small ribosomal subunit that yields a $1.6 \mathrm{~kb}$ fragment for first amplification (rPLU1: $5^{\prime}$ TCAAAGATTAAGCCATGCAAGTGA-3' and rPLU5: 5'-CCTGTTGTTGCCTTAAACTCC-3'). The inner speciesspecific labelled primers for the second amplification yielded a 205 bp fragment for $P$. falciparum were rFAL1 (Forward): 5'-Digoxigenin-TTAAACTGGTTTGGGAAA ACCAAATATATT-3' and rFAL2 (Reverse): 5' - BiotinACACAATGAACTCAATCATGACTACCCGTC-3 $[10,16,29-31]$. With these primers the LOD was only $1.35 \mathrm{ng}$ of DNA. Subsequent experiments used a second set of P. falciparum DHFR gene specific primers: U1 (Forward: $5^{\prime}$-GGAAATAAAGGAGTATTACCATG-3') and 
U2 (Reverse: 5'-Biotin-TAAGGTTCTAGACAATATAA CA-3'), which yields a 273 bp fragment in the primary amplification. Inner primer U3 (Forward: 5'-DigoxigeninGAAATGTATTTCCCTAGATATGgAATATT- $3^{\prime}$ ) and U4 (Reverse: 5'-Biotin-ATTTATCCTATTGCTTAAAGGT-3') $[10,16,30-34]$ were used in the second round of amplification and produced a $229 \mathrm{bp}$ amplicon. For the seminested asymmetrical PCR the U1 primer was labeled with digoxigenin. The PfDHFR primers were adopted as they attained superior detection threshold in parasite serial dilutions and in earlier work detecting P. falciparum from human saliva samples [11]. The primers also flank DHFR amino acid codon 108 for optional detection of anti-folate drug resistance-associated mutations.

\section{Molecular detection of Plasmodium falciparum}

A gene-specific nested PCR protocol developed by Dr. David Sullivan's group [11] was used in a conventional nested PCR as illustrated in Figure 1. To allow detection of P. falciparum PCR amplicons by lateral flow, forward primer U3 and reverse primer U4 were synthesized with biotin and digoxigenin haptens at their respective $5^{\prime}$-ends. The resulting biotin-digoxigenin tagged DNA amplicon was bound to UCP reporter particles coated with mouse-anti digoxigenin [35] and subsequently captured by an avidin test line on nitrocellulose lateral flow strips. The UCP fluorescence signal was detected by interrogating the strips with a $980 \mathrm{~nm}$ laser [35]. The ratio of the test line to the control line UCP signals observed is proportional to the amount of target molecule.

\section{Nested PCR amplification}

Conventional nested PCR for P. falciparum with the primer pair U1 and U2 yielding a $273 \mathrm{bp}$ amplicon (Figure 1A) was carried out as described by Mharakurwa et al. [11]. Using the $273 \mathrm{bp}$ amplicon as a template, the second round of PCR employed the nested primer pair U3 and U4 that amplifies a nested product specific for P. falciparum.

Briefly, both the first and second PCR amplifications were carried out in a total volume of $25 \mu \mathrm{l}$ consisting of $2 \mu \mathrm{l}$ template (0.5 $\mu \mathrm{l}$ for standard lab clone 3D7); $0.25 \mu \mathrm{M}$ of each primer; $1.5 \mathrm{mM}$ magnesium chloride; $0.2 \mathrm{mM}$ dNTPs; $1 \mathrm{X}$ PCR Buffer; and 1U Taq polymerase. The nested PCR amplification required a total of six hours to complete both the first and second amplifications. Using conventional nested PCR (Figure 1A), an initial amplification was performed using primers $\mathrm{U} 1$ and $\mathrm{U} 2$ and the following programme: $94^{\circ} \mathrm{C} / 2 \mathrm{~min} ;\left(94^{\circ} \mathrm{C} / 45 \mathrm{sec} ; 43^{\circ} \mathrm{C} / 45 \mathrm{sec} ; 65^{\circ} \mathrm{C} / 1 \mathrm{~min}\right) \times 25$ cycles after which $1.6 \mu \mathrm{l}$ was transferred to a second tube with fresh reagents and inner primers U3 and U4. Amplification using the same program was performed for an additional 25 cycles for a total run time of $\sim 3.5$ hours.

\section{Semi-nested asymmetric PCR}

Unlike conventional nested PCR, the semi-nested asymmetric PCR (Figure 1B) was performed in a single tube,

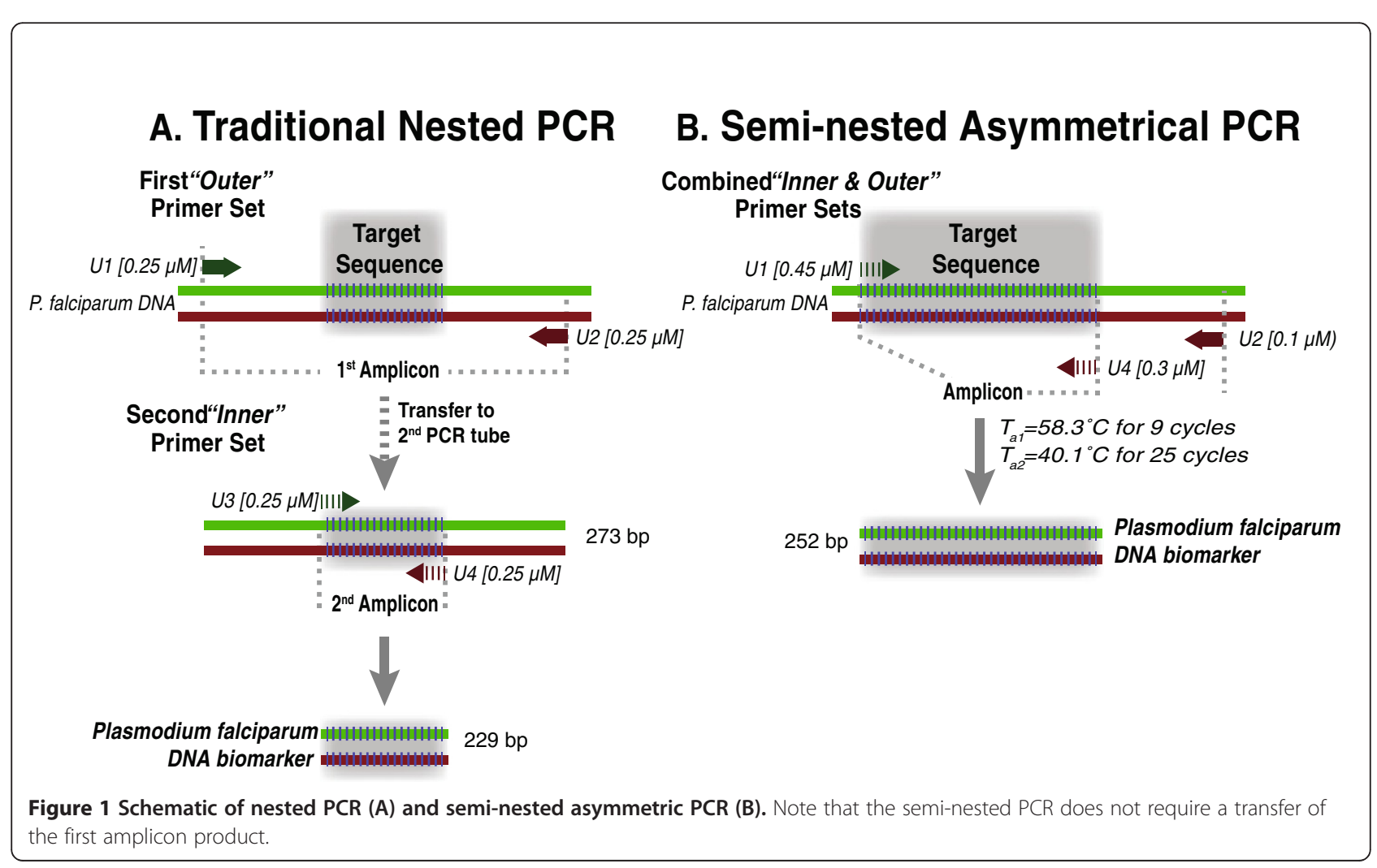




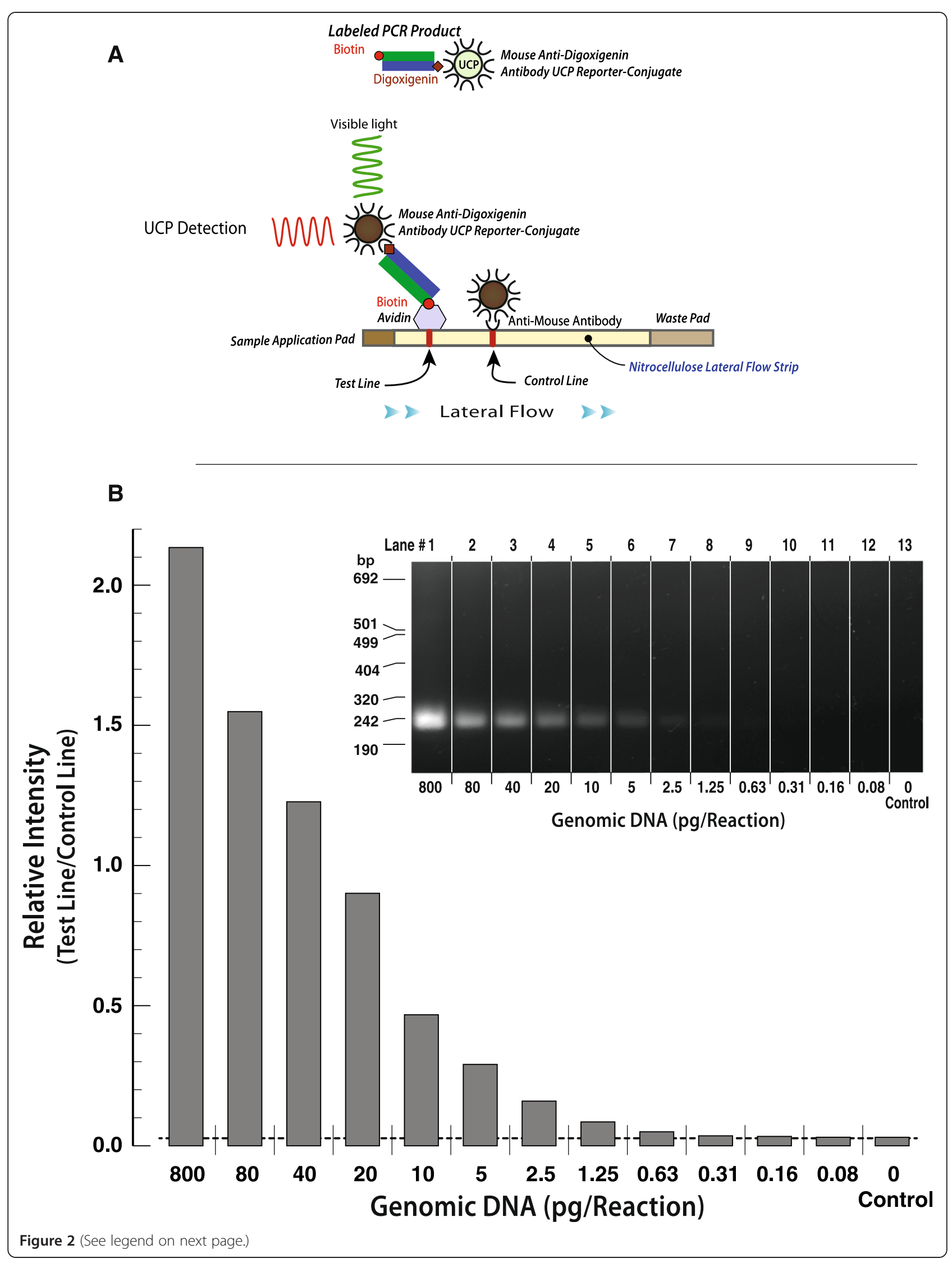


(See figure on previous page.)

Figure 2 PCR titration of genomic DNA using the genus specific primers. A) The schematic outlines the strategy for UCP detection. B) UCP detection of digoxigenin-biotin labelled amplicon generated from a serial dilution of $P$. falciparum DNA using semi-nested PCR. The equivalent \# parasites per reaction were $38084,3408,1704,852,426,213,107,53,27,13,7$, and 3, which corresponds to Lane numbers 1 through 12 on the image of the agarose gel. The insert is the ethidium bromide stained agarose gel (2\%), which confirms the resulting amplicon products as a function of the serial dilution of Plasmodium falciparum DNA. Each lane contained $18 \mu \mathrm{l}$ of the PCR product. The intensity of the phosphorescent UCP reporter particles was measured through excitation at $980 \mathrm{~nm}$ and emission at $455 \mathrm{~nm}$.

uninterrupted without transfer of amplicon using the following programme: $94^{\circ} \mathrm{C} / 2 \mathrm{~min} ;\left(94^{\circ} \mathrm{C} / 45 \mathrm{sec} ; 58^{\circ} \mathrm{C} /\right.$ $\left.50 \mathrm{sec} ; 65^{\circ} \mathrm{C} / 1 \mathrm{~min}\right) \times 9$ cycles; $94^{\circ} \mathrm{C} / 2 \mathrm{~min} ; 94^{\circ} \mathrm{C} / 45 \mathrm{sec}$; $\left.40^{\circ} \mathrm{C} / 50 \mathrm{sec} ; 65^{\circ} \mathrm{C} / 1 \mathrm{~min}\right) \times 25$ cycles; $65^{\circ} \mathrm{C}, 2$ min with a total running time of $\sim 1.5$ hours. The single-tube seminested PCR reaction, which generates a 252 bp amplicon, was performed in a total volume of $20 \mu \mathrm{l}$ containing $8 \mu \mathrm{l}$ template DNA; $0.45 \mu \mathrm{M}, 0.1 \mu \mathrm{M}$ and $0.3 \mu \mathrm{M}$, respectively of primers U1, U2 and U4; 1X PCR buffer, $0.2 \mathrm{mM}$ dNTP; $2 \mathrm{U}$ Taq polymerase.

\section{Lateral flow assay adaptation}

The PCR-generated digoxigenin-biotin labelled amplicon was analysed as previously described [35]. Briefly, $1 \mu \mathrm{l}$ of amplified PCR product was mixed with $100 \mathrm{ng}$ mouseanti digoxigenin-UCP conjugate dispersed in $100 \mu \mathrm{l}$ of lateral flow buffer (100 mM Hepes $\mathrm{pH} 7.2,270 \mathrm{mM} \mathrm{NaCl}$, $1 \%(\mathrm{w} / \mathrm{v})$ BSA, $0.5 \%(\mathrm{v} / \mathrm{v})$ Tween 20$)$ and incubated in a thermal shaker $\left(1,000 \mathrm{rpm}, 37^{\circ} \mathrm{C}\right)$ for $30 \mathrm{~min}$. The mixture was then added to a microtiter plate well containing a lateral flow nitrocellulose strip with a "test" line consisting of avidin and a "control" line of anti-mouse-digoxigenin [35].
The avidin test line captures the biotin labelled PCR amplicons bound to the UCP reporter as it flows on the lateral flow strip and the unbound UCP binds to the distal control line comprised of mouse anti-digoxigenin antibody. Following immunochromatography, the strips were dried and analysed for UCP using a Packard Fluoro Count $^{\mathrm{TM}}$ adapted with a $980 \mathrm{~nm}$ Infrared Opto Power Corp laser [27].

\section{Results}

The detection threshold of the conventional malaria-nested PCR was determined using a ten-fold serial dilution series of $P$. falciparum NF54 culture samples ranging from 800 to 0.0 .08 pg DNA per reaction $\left(\sim 3.4 \times 10^{4}\right.$ to $\sim 3$ parasites/reaction). The amplicons generated were detected by agarose gel electrophoresis and lateral flow UCP detection (Figure 2B). Figure 2A provides a schematic of the binding events occurring at the respective Test and Control lines for lateral flow detection. Negative controls lacked reactivity.

DNA was extracted from saliva specimens $(1 \mathrm{ml})$ obtained from negative and positive malaria patients with low-grade parasitaemia (ranging from microscopy negative

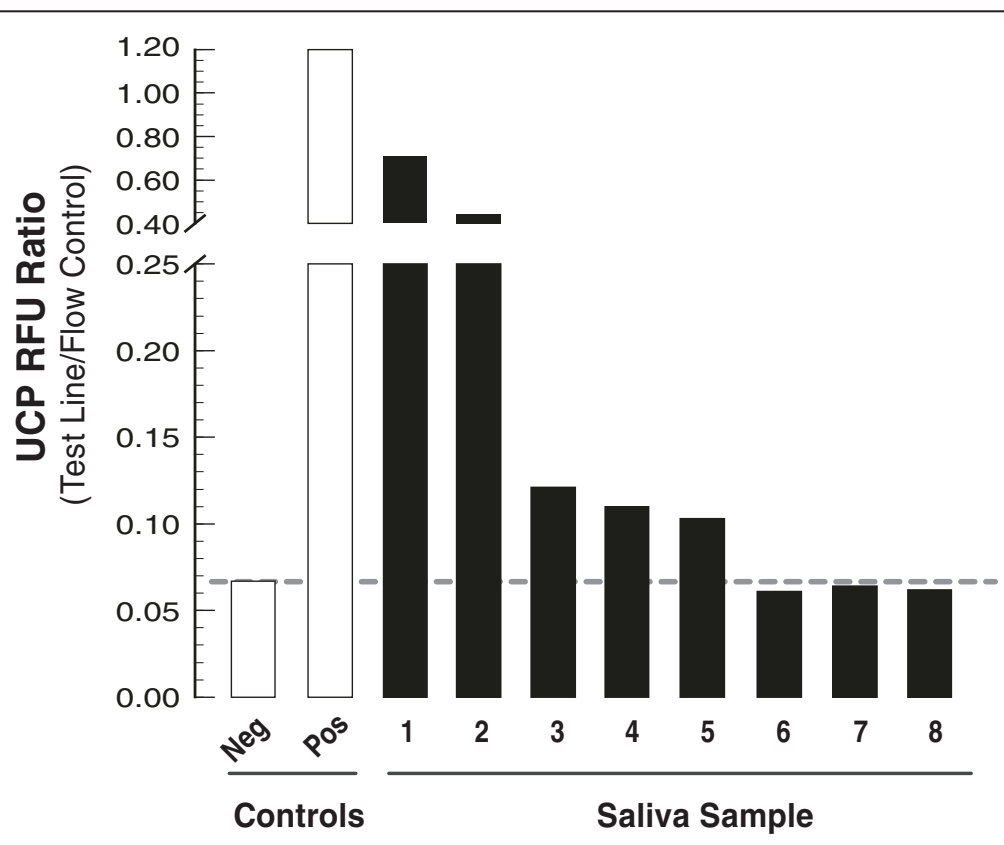

Figure 3 UCP detection analysis of clinical malaria saliva samples using the semi-nested asymmetric PCR protocol. UCP lateral flow assay: UCP reporter was used to detect the biotin-digoxigenin labelled amplicons generated using the single-step PCR amplification protocol. Parasite concentrations were determined using thick film microscopy of subject blood. The threshold is indicated as a horizontal dashed line. 
to $3 \times 10^{3}$ parasites/ $\mu$ l of peripheral blood), eluted in $200 \mu \mathrm{l}$, and $8 \mu \mathrm{l}$ of the eluted DNA template amplified by the semi-nested PCR. The results obtained by gels and UCP LF assay of the clinical samples were concordant with the subject's known malaria status and level of parasitaemia (Figure 3). These experiments successfully demonstrate proof-of-principle for uninterrupted single-tube PCR for detection of plasmodium DNA with both $P$. falciparum-positive laboratory control and clinical samples. In addition it is possible to utilize the semi-nested PCR approach for sensitive detection of $P$. falciparum in dried blood spots (Figure 4).

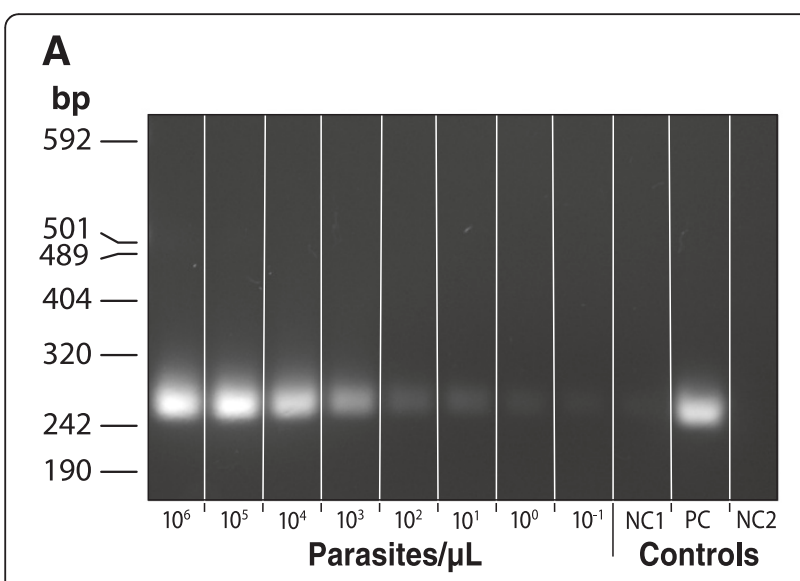

B

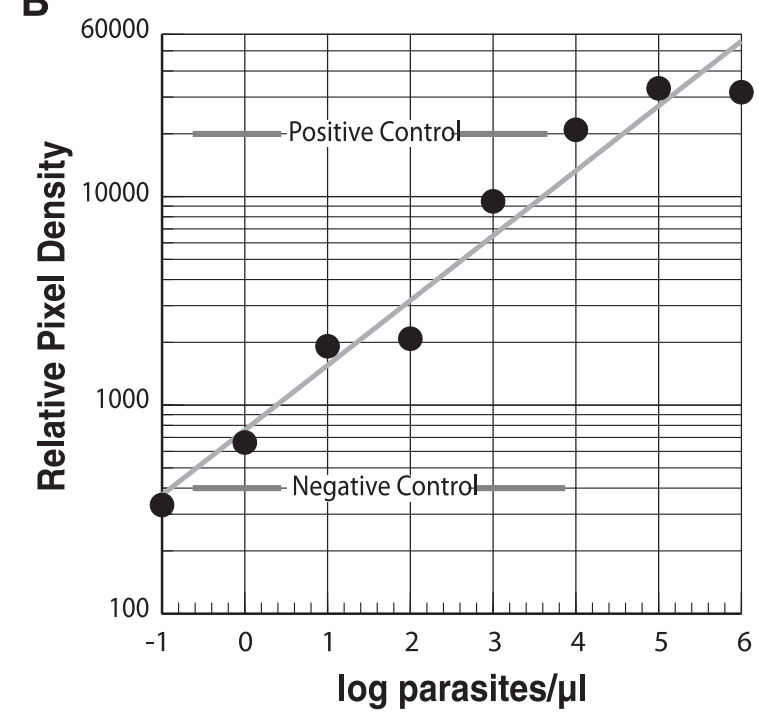

Figure 4 LOD of parasite DNA using semi-nested PCR from six 3-mm diameter stored dried blood spots. A) Amplicons are visualized in a $1.5 \%$ agarose gel stained with ethidum bromide. NC1 refers to a blood sample that was not spiked with any parasite and went through an identical DNA isolation and amplification to the rest the experimental samples. NC2 refers to PCR master mix to which PCR grade water was substitutes for eluted DNA as a control for contaminants in PCR reagents. B. Graph of the relative pixel density of the amplicon as a function of the parasite concentration.
The basis for the single-tube amplification is that the first nine annealing cycles favour efficient amplification of the primary $\mathrm{U} 1 / \mathrm{U} 2$ product, which subsequently serves as template for the secondary U1/U4 amplicon, both during the primary and secondary reactions. The 252 bp amplicon is most efficiently amplified at the annealing temperature of the subsequent 25 cycles. The concentration of $\mathrm{U} 1$ primer is highest, as it is used both in the primary and secondary reactions; $\mathrm{U} 2$ has the lowest concentration for the initial short (nine) primary annealing cycles, which minimizes competition with the secondary primer U4; and U4 has a standard primer concentration to serve in the 25 secondary cycles. In this approach, the primary amplicon rate of production gets a head start, but then slows as it provides template for the second amplification.

\section{Discussion}

The current experiments provide proof of principle for a malaria diagnostic that combines a quick semi-nested asymmetric PCR combined with a UCP lateral flow assay for the detection of $P$. faciparum DNA in saliva samples. A semi-nested asymmetric PCR that can detect $P$. falciparum DNA with a lower limit of detection comparable to that of the conventional nested PCR with both P. falciparum standard DNA as well as with saliva samples (Figure 3) was demonstrated. The sensitivity threshold for the original nested PCR strategy was equivalent to $\sim 1-10$ parasite/ $\mu$ l of peripheral blood sample $[29,36]$, which surpasses routine microscopy (40 parasites/ $\mu \mathrm{l})$ and RDTs (100 parasites/ $\mu \mathrm{l})$ (Figure 4). The more specific gene-directed primers were chosen to pursue the semi-nested PCR. The first step in the semi-nested PCR is at high annealing temperature, which is more specific, while the second step is at a lower temperature and less specific. PCR performed at low specific conditions (low $\mathrm{Ta}$ ) would generate non-specific products and/or false positives. The developed semi-nested asymmetric PCR minimizes the risk for contamination since it does not require sample carry-over to a second tube before starting the amplification of the nested fragment. Moreover, the semi-nested PCR only takes $\sim 1.5$ hours, which is $\sim 40 \%$ of the total time taken to run conventional nested PCR [10,11]. Furthermore, in comparison to gel electrophoresis, LF allows a more convenient quantitative analysis suited for point-of-care applications. With a limited number of clinical saliva samples the feasibility of the assay was demonstrated to correctly identify positive samples. Additional studies are required to conclude whether this assay is a good point-of-care alternative for testing saliva-based samples rather than the conventional nested PCR developed for analysing blood-based samples in a dedicated diagnostic laboratory. The development of automated microfluidic devices capable of performing the above-described analysis of either a saliva or blood sample 
is in progress [37]. Recently a self-heating microfluidic chip for genotyping mosquitoes has been described by Liu et al. [38].

\section{Conclusions}

This study demonstrates a semi-nested asymmetric PCR in a compressed time frame to detect $P$. falciparum DNA. The resulting digoxigenin-biotin tagged DNA amplicons are quantified using lateral flow and the sensitive UCP reporter technology. The assay reduces the chance of cross-contamination and can be readily configured as a POC assay using fresh or dried blood or saliva. The total assay time (including analysis) is reduced as compared to the conventional nested PCR approach with gel analysis. Integration of the new test into a microfluidic format using oral fluid has the potential to be used as an efficient non-invasive tool for POC applications, overcoming the limitations of microscopy and RDTs in detecting lowgrade reservoirs of infection.

\section{Competing interests}

The authors declare that they have no competing interests.

\section{Authors' contributions}

SYO, SM, EG, and CAB conducted experiments and analysed the results with WRA, PC, and DM, SYO, SM, PC, and WRA wrote the main paper. All authors discussed the results and implications and commented on the manuscript. All authors read and approved the final manuscript.

\section{Acknowledgements}

This project was supported by a National Institute of Dental and Craniofacial Research (NIDCR) Grant U01DE017855, a New York State Foundation for Science, Technology and Innovation (NYStar) award to DM, and a Gates Foundation grant to SM.

\section{Author details}

'Department of Basic Science, NYU College of Dentistry, New York, NY, 10010, USA. ${ }^{2}$ Department of Molecular Cell Biology, Leiden University Medical Center, Leiden, The Netherlands. ${ }^{3}$ Johns Hopkins University, Bloomberg School of Public Health, W Harry Feinstone Department of Molecular Microbiology and Immunology, Baltimore, USA. ${ }^{4}$ The Malaria Institute at Macha, PO Box 630166, Choma, Zambia. ${ }^{5}$ Current address: University of Delaware, Department of Biological Sciences, Newark, DE 19716, USA.

Received: 22 December 2012 Accepted: 18 February 2013 Published: 22 February 2013

\section{References}

1. WHO: World Malaria Report 2011. Geneva: World Health Organization; 2011

2. Murray CK, Gasser RA Jr, Magill AJ, Miller RS: Update on rapid diagnostic testing for malaria. Clin Microbiol Rev 2008, 21:97-110.

3. Hopkins H, Kambale W, Kamya MR, Staedke SG, Dorsey G, Rosenthal PJ: Comparison of HRP2- and pLDH-based rapid diagnostic tests for malaria with longitudinal follow-up in Kampala, Uganda. Am J Trop Med Hyg 2007, 76:1092-1097.

4. Moody AH, Chiodini PL: Non-microscopic method for malaria diagnosis using OptiMAL IT, a second-generation dipstick for malaria pLDH antigen detection. Br J Biomed Sci 2002, 59:228-231.

5. Ashley EA, Touabi M, Ahrer M, Hutagalung R, Htun K, Luchavez J, Dureza C, Proux S, Leimanis M, Lwin MM, et al: Evaluation of three parasite lactate dehydrogenase-based rapid diagnostic tests for the diagnosis of falciparum and vivax malaria. Malar J 2009, 8:241.

6. Maltha J, Gamboa D, Bendezu J, Sanchez L, Cnops L, Gillet P, Jacobs J: Rapid diagnostic tests for malaria diagnosis in the Peruvian Amazon: impact of pfhrp2 gene deletions and cross-reactions. PLOS One 2012, 7:e43094.

7. Van der Palen M, Gillet P, Bottieau E, Cnops L, Van Esbroeck M, Jacobs J: Test characteristics of two rapid antigen detection tests (SD FK50 and SD FK60) for the diagnosis of malaria in returned travellers. Malar J 2009, 8:90.

8. Mharakurwa S, Shiff CJ: Post treatment sensitivity studies with the ParaSight- $F$ test for malaria diagnosis in Zimbabwe. Acta Trop 1997, 66:61-67.

9. Mharakurwa S, Siame M, Thuma P: Adaptive changes in malaria transmission during scaled up interventions in Southern Zambia. In American Society for Tropical Medicine \& Hygiene $60^{\text {th }}$ Annual Meeting. Philadelphia, Pennsylvania, USA; 2011.

10. Snounou G, Singh B: Nested PCR analysis of Plasmodium parasites. Methods Mol Med 2002, 72:189-203.

11. Mharakurwa S, Simoloka C, Thuma PE, Shiff CJ, Sullivan DJ: PCR detection of Plasmodium falciparum in human urine and saliva samples. Malar $J$ 2006, 5:103.

12. Johnston SP, Pieniazek NJ, Xayavong MV, Slemenda SB, Wilkins PP, da Silva AJ: PCR as a confirmatory technique for laboratory diagnosis of malaria. J Clin Microbiol 2006, 44:1087-1089.

13. Buppan P, Putaporntip C, Pattanawong U, Seethamchai S, Jongwutiwes S: Comparative detection of Plasmodium vivax and Plasmodium falciparum DNA in saliva and urine samples from symptomatic malaria patients in a low endemic area. Malar J 2010, 9:72.

14. Jarra W, Snounou G: Only viable parasites are detected by PCR following clearance of rodent malarial infections by drug treatment or immune responses. Infect Immun 1998, 66:3783-3787.

15. Osman MM, Nour BY, Sedig MF, De Bes L, Babikir AM, Mohamedani AA, Mens PF: Informed decision-making before changing to RDT: a comparison of microscopy, rapid diagnostic test and molecular techniques for the diagnosis and identification of malaria parasites in Kassala, eastern Sudan. Trop Med Int Health 2010, 15:1442-1448.

16. Singh B, Bobogare A, Cox-Singh J, Snounou G, Abdullah MS, Rahman HA: A genus- and species-specific nested polymerase chain reaction malaria detection assay for epidemiologic studies. Am J Trop Med Hyg 1999, 60:687-692.

17. Montenegro LM, Montenegro RA, Lima AS, Carvalho AB, Schindler HC, Abath FG: Development of a single tube hemi-nested PCR for genusspecific detection of Plasmodium in oligoparasitemic patients. Trans $R$ Soc Trop Med Hyg 2004, 98:619-625.

18. Alam MS, Mohon AN, Mustafa S, Khan WA, Islam N, Karim MJ, Khanum H, Sullivan DJ Jr, Haque R: Real-time PCR assay and rapid diagnostic tests for the diagnosis of clinically suspected malaria patients in Bangladesh. Malar J 2011, 10:175.

19. Perandin F, Manca N, Calderaro A, Piccolo G, Galati L, Ricci L, Medici MC, Arcangeletti MC, Snounou G, Dettori G, Chezzi C: Development of a realtime PCR assay for detection of Plasmodium falciparum, Plasmodium vivax and Plasmodium ovale for routine clinical diagnosis. J Clin Microbiol 2004, 42:1214-1219.

20. Espy MJ, Uhl JR, Sloan LM, Buckwalter SP, Jones MF, Vetter EA, Yao JD, Wengenack NL, Rosenblatt JE, Cockerill FR 3rd, Smith TF: Real-time PCR in clinical microbiology: applications for routine laboratory testing. Clin Microbiol Rev 2006, 19:165-256.

21. Corstjens PL, Chen Z, Zuiderwijk M, Bau HH, Abrams WR, Malamud D, Sam Niedbala R, Tanke HJ: Rapid assay format for multiplex detection of humoral immune responses to infectious disease pathogens (HIV, HCV, and TB). Ann N Y Acad Sci 2007, 1098:437-445.

22. Chen Z, Mauk MG, Wang J, Abrams WR, Corstjens PL, Niedbala RS, Malamud D, Bau HH: A microfluidic system for saliva-based detection of infectious diseases. Ann N Y Acad Sci 2007, 1098:429-436.

23. Abrams WR, Barber CA, McCann K, Tong G, Chen Z, Mauk MG, Wang J, Volkov A, Bourdelle P, Corstjens PL, Zuiderwijk M, Kardos K, Li S, Tanke HJ, Sam Niedbala R, Malamud D, Bau H: Development of a microfluidic device for detection of pathogens in oral samples using upconverting phosphor technology (UPT). Ann N Y Acad Sci 2007, 1098:375-388.

24. Corstiens PLA, Malamud D: Point-of-care diagnostics for infectious diseases. In Salivary Diagnostics. Edited by Wong DT: Wiley-Blackwell Publisher; 136-149.

25. Malamud D, Niedbala RS: New York Academy of Sciences. Oral-based diagnostics. Boston, Mass: Published by Blackwell Pub. on behalf of the New York Academy of Sciences; 2007. 
26. Malamud D, Bau H, Niedbala S, Corstjens P: Point detection of pathogens in oral samples. Adv Dent Res 2005, 18:12-16.

27. Corstjens PL, Li S, Zuiderwijk M, Kardos K, Abrams WR, Niedbala RS, Tanke $\mathrm{HJ}$ : Infrared up-converting phosphors for bioassays. IEE Proc Nanobiotechnol 2005, 152:64-72.

28. Schneider CA, Rasband WS, Eliceiri KW: NIH Image to ImageJ: 25 years of image analysis. Nat Methods 2012, 9:671-675.

29. Snounou G, Pinheiro L, Goncalves A, Fonseca L, Dias F, Brown KN, do Rosario $\mathrm{V}$ : The importance of sensitive detection of malaria parasites in the human and insect hosts in epidemiological studies as shown by the analysis of field samples from Guinea-Bissau. Trans R Soc Trop Med Hyg 1993, 87:649-653.

30. Snounou G, Viriyakosol S, Jarra W, Thaithong S, Brown KN: Identification of the four human malaria parasite species in field samples by the polymerase chain reaction and detection of a high prevalence of mixed infections. Mol Biochem Parasitol 1993, 58:283-292.

31. Snounou G, Viriyakosol S, Zhu XP, Jarra W, Pinheiro L, Do Rosario VE, Thaithong S, Brown KN: High sensitivity of detection of human malaria parasites by the use of nested polymerase chain reaction. Mol Biochem Parasitol 1993, 61:315-320.

32. Snounou G, Pinheiro L, Goncalves A, Fonseca L, Dias F, Brown KN, Do Rosario VE: The importance of sensitive detection of malaria parasites in the human and insect hosts in epidemiological studies, as shown by the analysis of field samples from Guinea Bissau. Trans R Soc Trop Med Hyg 1993, 87:649-653.

33. Singh B, Cox-Singh J, Miller AO, Abdullah MS, Snounou G, Rahman HA Detection of malaria in Malaysia by nested polymerase chain reaction amplification of dried blood spots on filter papers. Trans $R$ Soc Trop Med Hyg 1996, 90:519-521.

34. Richard FA, Sehgal RN, Jones HI, Smith TB: A comparative analysis of PCRbased detection methods for avaian malaria. J Parasitol 2002, 88:819-822

35. Corstjens P, Zuiderwijk M, Brink A, Li S, Feindt H, Niedbala RS, Tanke H: Use of up-converting phosphor reporters in lateral-flow assays to detect specific nucleic acid sequences: a rapid, sensitive DNA test to identify human papillomavirus type 16 infection. Clin Chem 2001, 47:1885-1893.

36. Gama BE, Silva-Pires Fdo E, Lopes MN, Cardoso MA, Britto C, Torres KL, de Mendonca Lima L, de Souza JM, Daniel-Ribeiro CT, Ferreira-da-Cruz Mde F: Real-time PCR versus conventional PCR for malaria parasite detection in low-grade parasitemia. Exp Parasitol 2007, 116:427-432.

37. Chen Z, Abrams WR, Geva E, Dood CJ, González JM, Tanke HJ, Niedbala RS, Zhou P, Malamud D, Corstjens PLAM: Development of a generic microfluidic device for simultaneous detection of antibodies and nucleic acids in oral fluids. BioMed Research International 2013, 2013:12.

38. Liu C, Mauk MG, Hart R, Bonizzoni M, Yan G, Bau HH: A low-cost microfluidic chip for rapid genotyping of malaria-transmitting mosquitoes. PloS One 2012, 7:e42222.

doi:10.1186/1475-2875-12-74

Cite this article as: Ongagna-Yhombi et al:: Improved assay to detect Plasmodium falciparum using an uninterrupted, semi-nested PCR and quantitative lateral flow analysis. Malaria Journal 2013 12:74.

\section{Submit your next manuscript to BioMed Central and take full advantage of:}

- Convenient online submission

- Thorough peer review

- No space constraints or color figure charges

- Immediate publication on acceptance

- Inclusion in PubMed, CAS, Scopus and Google Scholar

- Research which is freely available for redistribution

Submit your manuscript at www.biomedcentral.com/submit
C Biomed Central 